\title{
Civil-military relations in Central and Eastern Europe and integration with NATO and the European Union
}

\author{
Stephen Blackwell*
}

\begin{abstract}
This article seeks to outline the relationship between the enlargement of NATO and the EU and the reform of civil-military relations in the countries of Central and Eastern Europe (CEE). The principal argument is that while NATO has taken the lead in providing assistance in this area, it is not equipped to support the fundamental changes in civil society that are needed to consolidate democratic oversight of the military and effective defense reforms. While the EU has not taken a prominent role in the reform of the CEE militaries, it will in the long-term have a more fundamental impact on civilmilitary relations owing to its greater interest in real societal transformation.
\end{abstract}

Key words: NATO, EU, civil-military relations, democratization

W

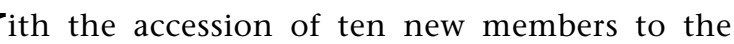
European Union (EU) and seven to the North Atlantic Treaty Organization (NATO) in 2004, the enlargement processes of both organizations have consolidated the already considerable impact they have had on the transitional development of the post-communist countries of Central and Eastern Europe (CEE). Over the next few years, this influence will continue to manifest itself both in terms of the conditions set by the two institutions for membership and demands from the candidate countries themselves for continued guidance in »setting the agenda « for the profound political, economic and social changes that have taken place. In contrast to areas such as Africa, the central importance of NATO and the EU to this reform process also to some extent reflects the way in which the United Nations (UN) has been sidelined as a result of its perceived inability to resolve the violent ethnic disputes in parts of the CEE region. In the aftermath of the conflicts that beset former Yugoslavia and briefly threatened the stability of Slovakia, Romania and Bulgaria, the focus has shifted to the admission of the CEE countries to the »Western Club « and the consolidation of democratic reforms in the region. ${ }^{1}$

This article seeks to discuss two key questions raised by the increased profile of the major Western security institutions in the region and the effect of this on armed forces reform in the CEE countries. The first is the extent to which NATO and EU enlargement has affected civil-military relations in the countries under discussion. The second concerns the na-

* Stephen Blackwell is Head of the European Security Programme at the Royal United Services Institute, London. He was previously European Editor of Jane's Sentinel Security Assessments, and a Visiting Lecturer at the University of Babes-Bolyai, Cluj, Romania, working for the Civic Education Project, an American NGO involved in a wide range of projects and tion Project, an American NGO involved in a wide range of projects and initiatives in Central/Eastern Europe and the former Soviet Union. He holds a PhD in International Politics from the University of Wales, Aberystwyth.

This article was prepared for the United Nations University-IFSH project »The Role of the Military in Post-Conflict Peacebuilding. "The author acknowledges the project directors Hans-Georg Ehrhart (IFSH) and Albrecht Schnabel (swisspeace), the members of the project team as well as two anonymous peer reviewers for their input in the preparation of this article.

1 Alex Pravda, »Introduction «, in Jan Zielonka and Alex Pravda, eds., DeAlex Pravda, "Introduction", in Jan Zielonka and Alex Pravda, eds., De-
mocratic Consolidation in Eastern Europe: Volume 2, International and Transnational Factors, Oxford and New York: Oxford University Press, 2001, pp. $1-27$. tional armed forces reform programs in relation to the accession processes. A central argument of this article is that EU and NATO objectives, often perceived as being synonymous, do in fact reveal different priorities with regard to the reform of civil-military relations in the CEE countries. An analysis of the relationship between EU and NATO enlargement policies, a subject that remains under-researched at present, highlights the danger of both institutions pursuing different aims that in turn could lead to distortions of the reforms that are currently undertaken. The conflicting demands of what could be termed »relative conditionality « and the lack of a formalized link between the two enlargements need to be addressed if the conditions for "correct " civil-military relations, an essential component of democratization and security sector reform, are to be established in the CEE region. ${ }^{2}$

\section{Problems of civil-military reform in the post- communist CEE countries}

This article deals with those CEE countries that are either embarked on accession negotiations with NATO and the EU, or at least aspire to do so. While it is difficult to generalize about states as diverse as, for example, the Baltic countries and the successor states of the former Yugoslavia, it is suggested here that all of the post-communist states share fundamental difficulties in their efforts to reform their civilmilitary relations. According to one assessment of the main issues, the military in the CEE states face a »triple set of transition challenges « in relation to their reform: justification of expenditure, personnel recruitment and the requirement to be »adaptive learning organizations. «A major issue for the CEE states is the impact of rapid downsizing and the potential hazards this creates in terms of declining

2 »Correct civil-military relations « is a contentious issue in view of new research in this area. As well as the »traditional « models developed by Samuel P. Huntington and Morris Janowitz in the 1950s and 1960s (see footnotes $4 \& 5$ ), new insights dealing with the CEE countries can be found in David Betz and John Löwenhardt, eds., Army and State in Postcommunist David Betz and John Löwenhardt, eds., Army and State in Postcommunist
Europe, London: Frank Cass, 2001, and Andrew Cottey, Timothy Edmunds and Anthony Forster, eds., Democratic Control of the Military in Postcommunist Europe: Guarding the Guards, Basingstoke: Palgrave, 2002. 
military morale and the social disruption caused by the unemployment of large numbers of officers and recruits. ${ }^{3}$ At this point it is worth expanding on what is meant by »civilmilitary relations « within the context of security sector reform in order to define more clearly the principal difficulties faced by the CEE governments since 1989 .

Although the argument developed here uses civil-military relations as a generic term, the issues dealt with can in fact be subdivided into two inter-connected spheres of policy activity: civil-military relations and military-society relations. Civil-military relations in this sense refer to the totality of mechanisms aimed at ensuring that the military within a given country is effectively managed by the executive, is subject to the efficient scrutiny of a democratic legislature and is fully accountable to the principal branches of government. This vision of a professionalized and de-politicized military corresponds with Samuel Huntington's conception of »objective political control. ${ }^{4}$ Military-society relations, on the other hand, concern the relationship between the armed forces and society in a broader sense, and the political and sociological issues raised by this form of interaction. The assumption is that society and the military must be truly engaged with and representative of each other, with the military consequently under »subjective military control.« There is thus arguably a correlation between the levels of public interest in, or »civic society « activity connected with, a country's armed forces and their political and democratic characteristics. ${ }^{5}$

Bearing this expanded definition in mind, it is possible to discern common features in the nature of the civil-military relations »experience « shared by the CEE countries that emerged from communist rule in 1989. Among these was a high degree of politicization of the members of the military sector, a consequence of the rigid ideological conformity imposed by single party communist systems. The previous aim of "politicizing « the military necessitated strong civilian control of the armed forces as institutions, although this was to some extent paradoxically combined with a high degree of military autonomy in the actual framing of defense policy. This common experience was the source of many of the difficulties encountered by post-communist militaries following the collapse of the former regimes. Taking Western models of civil-military relations as an example, the armed forces in the CEE region were seen as encumbered by a sudden obsolescence not only in terms of military doctrine and equipment, but also their political relationship with the new social order. This was particularly the case given the starkly interrelated problems of a politically active military combined with the absence of any traditions of parliamen-

3 Anthony Forster, Timothy Edmunds and Andrew Cottey, eds., The Challenge of Military Reform in Postcommunist Europe: Building Professional Armed Forces, Basingstoke: Palgrave, 2002, pp. 1-17.

4 Samuel P. Huntington, The Soldier and the State: The Theory and Politics of Civil-Military Relations, Cambridge, Mass.: Harvard University Press, 1957.

5 Morris Janowitz, The Professional Soldier: a Social and Political Portrait, London: Glencoe Collier-Macmillan, 1960. tary oversight, financial management systems or defense expertise in the civilian sector. ${ }^{6}$

One of the main concerns expressed by both international and regional actors in the early 1990s was that military elites in the CEE countries would be tempted to intervene in order to either replace or exercise a direct form of control over weak civilian regimes. Despite these fears of the threat of »Praetorianism, « defined as military intervention by coups or other means in the civilian political administration of a state, has remained unrealized. The tendency towards political non-interference shown by the armed forces in CEE has, paradoxically, been attributable to the high degree of political sensitivity shown by a new breed of officers anxious to take advantage of the breakdown of the self-imposed isolation that characterized regional countries before $1989 .^{7}$ Exposure of the military to Western civil-military practice and strategic doctrine - in particular through NATO's Partnership for Peace (PFP) program - has also highlighted a pressing need for assistance with the reform process that is perceived as being available only from the United States and the EU countries. This has ranged from advice on establishing suitable civil-military structures to urgent requests for modern equipment to help upgrade and professionalize armed forces in the region. ${ }^{8}$

Perhaps most significantly, Western help has been sought with the institutional reform of civil-military relations in the CEE countries. Attempts to create »civilianized « ministries of defense in the region have so far run into the problems posed by the absence of trained civilian managers that would be competent enough to master the complexities of administering military forces. A common difficulty faced by all of the post-communist states to varying degrees is the absence of a tradition of an honest and efficient bureaucratic structure with a particular expertise in this field. The reform process has led to markedly variable results in the region, which has often revealed a serious gap between good intentions and bad implementation. Although Hungary was seen as perhaps the most enthusiastic reformer in the early 1990s, NATO officials have been disappointed with the inability of Budapest to formulate clear strategic doctrines. In contrast, Poland, while a slow starter in the aftermath of 1989, has adapted relatively smoothly to NATO membership. ${ }^{9}$ An analysis of the development of civil-military relations in CEE thus has to take account of the broader context of major societal change. As Betz, Löwenhardt and Strachan argue succinctly, »it is far more difficult in reality to introduce democratic principles of control into civil-military relationships that have been rigidly hierarchical, and to do so in

6 Andrew Cottey, Timothy Edwards and Anthony Forster, »Introduction: the Challenge of Democratic Control of Armed Forces in Postcommunist Europe", in Cottey, Edwards and Forster, Democratic Control of the Military in Postcommunist Europe, Basingstoke: Palgrave, 2001, pp. 1-17.

7 Dale R. Herspring, „Civil-Military Relations in Post-Communist Eastern Europe: The Potential for Praetorianism«, Studies in Comparative Communism, Vol. 25, No. 2, June 1992, pp. 99-122.

8 Jess Pilegaard, Defence Reform in Central Europe, IIS Report 2003/5, Copenhagen: Danish Institute for International Studies, 2003

9 See Jeffrey Simon, Poland and NATO: A Study in Civil-Military Relations, Lanham MD: Rowman \& Littlefield, 2004. 
a political situation that is changing quickly and is generating uncertainty and insecurity for its major players. $\ll^{10}$

It is important to note in summary that civil-military reforms in the CEE region have been affected by a degree of organic change in the post-Cold War security agenda, which is reflected both in changes in the role of the military and relative political marginalization of the armed forces within the democratization process. Economic considerations, the possibility of military modernization and the need for closer links with the West have ensured that the military has supported democratization and reform efforts. In a more general sense a »push-pull « relationship has emerged between the democratization process in CEE countries and the enlargement of NATO and the EU. The twin enlargement processes have grown both from the Western perception that this would serve the interests of security in the region, and also from the need of local regimes for help with the establishment of democratic, free-market systems. The existence of a »Western Project « in the region, debatable in terms of the actual co-ordination between outside international actors, is certainly perceived as a collective effort by regional governments. The EU and NATO in particular have become central to the foreign policies of the regional states, and membership in both of these organizations symbolizes their explicit aim of a »return to Europe. ${ }^{11}$

\section{The role of NATO and the EU}

In the period since the collapse of the communist regimes in the CEE states, Western policies aimed at promoting democratization in general have often been criticized for an absence of strategic direction. This criticism is certainly valid in view of the fact that the objectives of NATO and the EU in relation to the stated aim of enlargement and assistance with the reform of civil-military relations in the region remain undefined and only vaguely coordinated. Although both institutions have the same aim of real democratic control of armed forces, at ease with their roles within the states of the region, the process has been distorted by the perception that this policy area is primarily the concern of the Atlantic Alliance. Bearing in mind the elements referred to earlier, this has ensured a focus on efficient civil-military structures in an operational sense, at the expense of fundamental democratic reform and social participation in defense and security affairs. In view of the EU's potentially far more detailed interest in a process that will hopefully lead to basic changes in outlook as well as institutional structures, the policy of the Union towards civil-military reform remains relatively undefined. This is perhaps all the more surprising given the EU's recent experience in its expansion southwards to include NATO allies undergoing a process of

10 David Betz, John Löwenhardt and Hew Strachan, "Introduction«, Journal of Communist Studies and Transition Politics, Special Edition on "CivilMilitary Relations in Transition«, Vol. 17, No. 1, 2001, p. 4.

11 Karen E. Smith, »Western Actors and the Promotion of Democracy«, in Zielonka and Pravda, eds., Democratic Consolidation in Eastern Europe, pp. 31-3. change from military to democratic civilian governments during the 1970s and 1980s. ${ }^{12}$

NATO has taken the major role in the reform of civilmilitary structures in the CEE region for obvious reasons. Since 1989 the Alliance's increased interest in the area in general, and its willingness to undertake »out of area « military operations in former Yugoslavia in particular, has resulted in the Alliance taking over the initiative from the other major multinational institutions concerned with security in the region. Although the UN and the EU were initially responsible for initiatives aimed at resolving the vicious ethnic strife that broke out in the constituent republics of Yugoslavia in the early 1990s, NATO action was eventually the decisive factor. This stemmed from the perceived need both for military intervention and the fact that the Alliance alone, quite apart from its traditional doctrine of »collective defense, « possessed the ability to impose itself by force in order to quell the conflicts. To a great extent NATO's role in the resolution of the Yugoslav issue was thus reactive and featured considerable improvisation in the face of fluid circumstances on the ground. According to a former commander of the Alliance's Second Tactical Air Force, it was »difficult for NATO to stand aloof from events in which the UN was incompetent to act but for which NATO was well equipped, and which took place close to the Treaty borders. ${ }^{13}$

As well as overt displays of force aimed at settling disputes in the region, an explicitly stated motive behind NATO's policy of enlargement is the process of democratization in the CEE countries, with the aim of creating politically stable Alliance candidates with efficiently functioning armed forces. The PFP, launched by a meeting of the North Atlantic Council in Brussels in 1994, included an offer to »work in concrete ways towards transparency in defense budgeting [and] promoting democratic control of defense ministries. ${ }^{14}$ Indeed, a key argument used to support expansion is protection against domestic military intervention caused by economic crises in the countries that aspire to join the Western security structures. The Alliance's stated requirements for effective civil-military relations in the region include civilian ministers of defense, civilian officials in defense ministries, the exclusion of the military from partisan politics, legislative control of the defense budget and the open discussion of defense issues. The former American Secretary of State Madeleine Albright hoped in 1997 that the prospect of NATO membership would ensure that in the former communist states »soldiers take orders from civilians, not the other way around. $\ll^{15}$

12 See John Chipman, ed., NATO's Southern Allies: Internal and External Challenges, London \& New York: Routledge, 1988.

13 Roger Palin, »Multinational Military Forces: Problems and Prospects«, Adelphi Paper 294, International Institute for Strategic Studies, Oxford and New York: Oxford University Press, 1995, p. 6.

14 Declaration Issued by the Heads of State and Government Participating in the Meeting of the North Atlantic Council, Brussels, 10-11 January 1994, in Christopher Hill \& Karen E. Smith, eds., European Foreign Policy: Key Documents, London \& New York: Routledge, 2000, Document 3/9, pp. 217-21.

15 Cited from Dan Reiter, »Why NATO Enlargement Does Not Spread Democracy«, International Security, Vol. 25, No. 4, 2001, pp. 54-6. 
Although the EU is very much concerned with democratization in policy areas such as civil-military relations, this has not manifested itself in terms of an explicit set of accession requirements or a general enunciation of principles. The negotiations aimed at the admission of new members have been led by the European Commission and thus have reflected those legal, economic and trade issues that reflect both the Commission's considerable competence in these areas and the primary interests of the aspiring members. Within the process of the European Commission's discussion with the CEE candidate countries the »chapter « dealing with the Common Foreign and Security Policy (CFSP), chapter 27, was closed with all twelve applicants well before the decision to admit ten of these countries at the EU's Copenhagen summit in 2002. This reflects the fact that no distinctive acquis communitaire exists in the field of foreign and defense policy. In particular, there is very little explicit linkage between the EU's external policies and the enlargement process itself, an omission that reflects both the Commission's relatively minor role in the CFSP (compared to the European Council representing the member states) and the embryonic nature of the policy itself. ${ }^{16}$

In the case of the EU, the present candidate countries, preoccupied as previously noted with more difficult areas of negotiations such as trade harmonization, have so far displayed little interest in military and defense issues. One exception in this context has been the Stability Pact for South Eastern Europe, the principal aim of which is to foster security in the region through economic and political reform. Security and defense issues are dealt with under »Working Table Three, « which has a »Sub-Table on defense and security issues « concerned with defense economics among other issues. However, the Stability Pact has no resources of its own and does not directly manage the projects; the Pact has acted merely as a mechanism through which bilateral assistance has been provided to the region. Progress depends on partnerships, and the Pact therefore has limited scope to provide roadmaps such as NATO's Membership Action Plans. ${ }^{17}$ The Atlantic Alliance has made a much more explicit link between its accession process, stability and reforms in areas such as civil-military relations. In contrast, the link is entirely absent from EU enlargement policy. There is a need for the EU to create a more explicit link between enlargement, the CFSP and military reform in conjunction with a clearer acquis in the fields of foreign and defense policy making. ${ }^{18}$

Notwithstanding the absence of clear criteria for accession, the promise of integration with both NATO and the EU has nevertheless had a distinct impact on democratic reforms in the CEE states. The process of EU accession by its very nature required a far more profound process of political, eco-

16 Mark Webber, "NATO Enlargement and European Defence Autonomy «, in Jolyon Howarth and John T. S. Keeler, eds., Defending Europe: The EU, NATO and the Quest for European Autonomy, Basingstoke: Palgrave Macmillan, 2003, pp. 157-80.

17 See the website of the Special Co-ordinator of the Stability Pact (http://www.stabilitypact.org)

18 Antonio Missiroli, ed. Bigger EU, wider CFSP, Stronger ESDP? The view from Central Europe, European Union Institute for Security Studies, Occasional Paper No. 34, April 2002. nomic and social readjustments, not the least being the diminution of sovereignty, than those required for NATO membership. As the EU, through the acquis, has set criteria for extremely detailed and comprehensive reforms in the run-up to accession, it is perhaps best placed to have an organic, »bottom-up« influence on the development of military-society as well as civil-military relations in the future. Yet the EU's input in this area remains small, and there is an urgent need for greater involvement in the reform of the armed forces in the CEE region, particularly given the increased importance of the embryonic European Security and Defense Policy (ESDP).

\section{Future prospects for civil-military reform in the CEE region}

Aside from the contention that the EU might be better placed to fundamentally change attitudes to civil-military relations, the partnership and development programs spearheaded by the PFP have also come under criticism for their detailed content. Within the context of efforts to ensure the creation of stable democratic institutions for the management of armed forces in the CEE region, the most pressing problem remains the »knowledge imbalance « between the civilian and military sectors. In the case of NATO, the promise of either accession or closer cooperation has meant that the prioritization of technical military issues, in particular interoperability, has led to the marginalization of the problem of encouraging a greater level of civilian participation in this sphere of activity. This is felt to be particularly true in the context of the PFP program, even though the initiative has sought to promote the development of essential elements of democratic control such as civilian expertise and parliamentary accountability. In reality PFP has been only partially successful in its aims. Although programs do exist for civilians, the overwhelming majority of participants from the CEE countries have been military personnel. This bias in the nature of the activities aimed at providing assistance has actually tended to widen the »expertise gap between the military and civilians. ${ }^{19}$

The inability to foster a culture of informed debate about defense and security matters in the region remains a cause for concern. There is broad agreement in the CEE region on the need for a stronger »strategic community involving all elements of society in a vigorous discussion of the future role of military forces. A key factor in this process will be the achievement of a healthy balance between the input of international organizations such as NATO and the EU and political leadership on the part of local politicians, civil servants, journalists and NGOs. The process will inevitably be incremental and it is important that national particularities

19 Jeffrey Simon, »The PFP Path and Civil-Military Relations«, in Simon, ed., NATO Enlargement: Opinions and Options, Washington DC: National Defense University, 1995, pp. 45-67. 
and requirements are respected..$^{20}$ The situation that persists even in those countries that entered NATO in 1997 indicates the difficulty of achieving the right balance in their reform programs. A recent examination of the defense reform process in Hungary has warned that NATO initiatives have virtually institutionalized the shortfall in civilian expertise and only partially addressed the problem of the relatively low status of the military in Hungarian society. ${ }^{21}$

NATO enlargement and the Alliance's increased engagement in CEE will not be an automatic panacea for the problems associated with civil-military relations in the region. More emphasis is needed on support for efforts to develop military-society relations with an emphasis on a "strategic civil society « rather than an inevitably conflictual relationship between governments and their armed forces. Many of the problems faced by the military establishments in the CEE countries are compounded by rapidly changing conceptions of what armed forces are necessary for, if they are necessary at all. In view of the special problems caused by ethnic tension in South Eastern Europe, there are strong arguments in favor of discarding doctrines of territorial defense in favor of a role for regional forces based on multinational coalitions and »non-traditional « (primarily humanitarian) military operations. The growth of military multinationalism and the move away from established assumptions about the roles of armed forces reflect the "post-modern military « paradigm increasingly promoted by security analysts. Indeed, a strong argument can be made that several features of this paradigm already predominate in the CEE region. ${ }^{22}$

Questions nevertheless remain over the role of the Atlantic Alliance. The PFP's focus on interoperability will inevitably take precedence over details of the democratic reform process, and past evidence would indicate that NATO could live with »quasi-authoritarian « regimes. Another disadvantage that stems from NATO taking the lead on civil-military reform in the CEE countries is that reform efforts have invariably taken on a technocratic »top-down « approach to problems that arguably require a more fundamental reappraisal. In particular the theoretical insights derived from »New Institutionalism, « with its focus on the values and norms that transcend the formal structures of policy-making and executive authority, is potentially valuable for an analysis of this issue. Within the concept of »New Institutionalism « is the notion of "path dependency « and the argument that »once an historical choice has been made, it both precludes and facilitates others. ${ }^{23}$ Thus, along with the difficulties institutions have with setting policy it also becomes extremely difficult to change policy, a problem compounded

20 For a critical view see Dušan Reljic, »Who Builds Civil Society? Civil Society, Mass Media and Democracy in the Post-Communist Countries«, Geneva Centre for the Democratic Control of Armed Forces, DCAF Working Paper No. 131, January 2004 (http://www.dcaf.ch/publications/Working_Papers/131.pdf).

21 James Sherr, "NATO's New Members: A Model for Ukraine? The Example of Hungary«, Paper G86, Conflict Studies Research Centre, RMA Sandhurst, September 2002 (http://www.csrc.ac.uk/pdfs/g92-vgb.pdf).

22 Charles C. Moskos, John Allen Williams and David R. Segal, "Armed Forces after the Cold War «, in Moskos, Williams and Segal, eds., The Postmodern Military: Armed Forces after the Cold War, New York \& Oxford: Oxford University Press, 2000, pp. 1-13.

23 Stephen Krasner, "Approaches to the State«, Comparative Politics, Vol. 16, No. 2, 1984, pp. 223-46. by the tendency of the institutional structures of both states and multinational organizations to bargain rather than seek an objective problem solving approach. The EU is as equally prone to this tendency as NATO, but it is to be hoped that the pressures leading to fundamental social change as a result of accession will have an impact on attitudes as well as institutional reform.

\section{Conclusion}

The uncertainties created by the sudden collapse of the communist regimes in the CEE region in 1989 highlighted the urgent need for modernized civil-military structures as part of a broader security sector reform process in these countries. This factor, compounded by the increased regional profiles of NATO and the EU, the promise of accession to both of these organizations and the "conditionality« factor inherent in this process, has led to the dominance of a »top-down « approach to reform. What is now required is an increased emphasis on a »bottom-up « approach in the form of aid that encourages open debate and a new focus on the participation of civil society. This will help to consolidate the aim of the new members to participate effectively in NATO and ESDP operations. While much progress has been made in the context of civil-military relations, much remains to be done on military-society relations. Concepts such as »civic society« and »citizen awareness « are notoriously difficult to define, but the very nature of EU enlargement makes this organization both considerably more competent and interested in genuine societal transformation than NATO. In their efforts to join Western security institutions, the contribution that the CEE countries can make as stable democracies with a growing sense of civic responsibility and accountability has at least the same importance to both NATO and the EU as geostrategic and military considerations. 